Southern Illinois University Carbondale

OpenSIUC

Publications

Department of Political Science

9-2007

\title{
A Neo-Institutional Explanation of State Supreme Court Responses in Search and Seizure Cases*
}

Scott A. Comparato

Southern Illinois University Carbondale, scompara@siu.edu

Scott D. McClurg

Southern Illinois University, mcclurg@siu.edu

Follow this and additional works at: http://opensiuc.lib.siu.edu/ps_pubs

\section{Recommended Citation}

Comparato, Scott A. and McClurg, Scott D. "A Neo-Institutional Explanation of State Supreme Court Responses in Search and Seizure Cases*." (Sep 2007).

This Article is brought to you for free and open access by the Department of Political Science at OpenSIUC. It has been accepted for inclusion in

Publications by an authorized administrator of OpenSIUC. For more information, please contact opensiuc@lib.siu.edu. 


\title{
A Neo-Institutional Explanation of State Supreme Court Responses in Search and Seizure Cases*
}

\author{
Scott A. Comparato** \\ Assistant Professor \\ scompara@siu.edu \\ Work: 618-453-3193 \\ Home: 618-529-7578 \\ Scott D. McClurg*** \\ Associate Professor \\ mcclurg@siu.edu \\ Work: 618-453-3191 \\ Home: 618-457-8888 \\ Department of Political Science \\ Southern Illinois University \\ 1000 Faner Drive \\ Mailcode 4501 \\ Carbondale, Illinois 62901-4501 \\ Fax: 618-453-3163

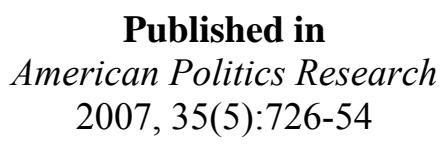

Keywords: Compliance; State Supreme Courts; Judicial Behavior

* Earlier versions of this paper were presented at the 2002 Annual Meeting of Midwest Political Science Association and the 2002 Annual Meeting of the Southern Political Science Association. We would like to thank Laura Langer for sharing her data and Jody Pennington for her diligent research assistance. We are also grateful to Stephen Wasby, William McLean, and Donald Songer for their comments. All errors remain our own.

**Scott A. Comparato is an Assistant Professor of Political Science at Southern Illinois University

***Scott D. McClurg is an Associate Professor of Political Science at Southern Illinois University.

This is a pre-typeset version of a peer-reviewed paper published in American Politics Research developed for deposit on the SIUC institutional repository. All references should refer to the published version, details given above. 


\section{A Neo-Institutional Explanation of State Supreme Court Responses in Search and Seizure Cases}

The relationship between the Supreme Court and lower courts is more complicated than it may appear at first glance. In order to better understand this relationship, we examine how Supreme Court precedent affects state supreme court decision-making. Toward this

end, we investigate whether and how Supreme Court precedent impacts lower court decisions. Examining state supreme court decisions in the area of search and seizure, we specifically test hypotheses about how state judicial context and Supreme Court behavior influences when the lower court is likely to be affected by Supreme Court precedent. We address the nature of state supreme court responses to Supreme Court precedent in search and seizure cases decided between 1983 and 1993. We find that there is substantial variation in the responses to precedent by state supreme courts. Specifically, we find that precedent does have a substantial influence on the behavior of state supreme court justices, but judicial ideology and the level of historical conflict between the Supreme Court and the state supreme court are also important in understanding the dissemination of precedent to the states. Most interestingly, the effect of judicial retention methods on the application of precedent are considerable. 


\section{Introduction}

There exists a diverse body of research on how lower courts are impacted by Supreme Court precedent (Beiser 1968; Benesh and Reddick 2002; Gruhl 1980; Johnson 1979; Klein and Hume 2003; Emmert and Traut 1994; Hoekstra 2005; Romans 1974). To the extent that state supreme courts have been the subject of such work, the findings suggest that they are attentive to precedent but vary notably in their application of the Court's decisions. At times, Supreme Court precedent appears to have a tangible influence on the outcomes of the decisions of state supreme court justices, while in other contexts the ideology of the justices or state level political factors serve to mitigate the power of precedent.

The relationship between the Supreme Court and lower courts is therefore more complicated than it may appear at first glance. In order to better understand this relationship, we examine the impact of Supreme Court precedent on state supreme court decision-making. Examining state supreme court decisions in the area of search and seizure, we assess how state judicial context and Supreme Court precedent influences how state courts respond to the precedent they cite. Our findings suggest that the judicial retention system and the degree of Supreme Court monitoring of the state supreme court are of primary importance in understanding the responses of state supreme court justices to Supreme Court precedent. Specifically, justices in merit retention states are more attentive to precedent of the Supreme Court than justices in either elite or competitive election systems. 


\section{The Impact of Supreme Court Decisions on Lower Courts}

Judicial decision-makers are influenced by a complex array of factors, including their own preferences (Brace, Langer, and Hall 2000; Segal and Spaeth 2002) and the political environment (Epstein and Knight 2000; Maltzman, Spriggs, and Wahlbeck 2000). But the decisions of other courts, especially higher courts, are also important. Partly this is because precedent is a guide for how to make decisions in the presence of specific fact patterns (Emmert 1992; Emmert and Traut 1994; George and Epstein 1992; Segal 1984, 1986; Segal and Spaeth 2002). It is also because precedent is a normative guide for lower courts, especially in cases with novel fact pact patterns (Knight and Epstein 1996; Landes and Posner 1976; Hansford and Spriggs 2006; Wahlbeck 1997).

Nevertheless, there is considerable debate about the ability of higher courts to get lower courts to adhere to their decisions. Much of the work on the role of precedent focuses on the hierarchical nature of the federal court system, analyzing how the lower court's political preferences interact with the Supreme Court's limited ability to monitor them to produce variations in lower court behavior (Benesh and Reddick 2001; Dickson 1994; Gruhl 1980, 1981; Johnson 1979; Romans 1974; Tarr 1977; Wasby 1970). Recent research on the federal circuit courts indicates that the Supreme Court's limited ability to hear cases affects both which courts they tend to review (Cameron, Segal, and Songer 2000) and the extent to which lower court justices "shirk" in order to pursue their own policy interests (Songer, Segal, and Cameron 1994; but see also Cross 2005).

To what extent do these conclusions apply to state supreme courts? Does Supreme Court precedent effect the decisions of state justices? Or, are their own political preferences more important, behaving as if they are not subject to the Supreme Court's 
authority? Do state judicial institutions affect their susceptibility to monitoring by the Supreme Court? The answers to these questions are not clear, primarily because the relationship between state courts and the Supreme Court is not strictly hierarchical. That is, not all decisions handed down by the state supreme courts are liable to Supreme Court review. This means that, in addition to factors that may allow all lower courts to avoid implementing decisions of the Supreme Court, state supreme courts can also rely on their own state constitutions and laws to determine the outcome of a case when issues of federal law are not implicated. Such reasoning indicates that the United State Supreme Court should have no more than a limited effect on the behavior of these courts.

But this is not necessarily the case. First, Supreme Court precedent might be a useful strategic tool for state judicial actors who are seeking to justify unpopular decisions for state voters and elites. Since a large majority of state supreme court justices are not lifetime appointees and are therefore subordinates in local state political hierarchies, their specialized knowledge of Supreme Court precedent may allow them to "shirk" locally. Second, state supreme courts are not entirely independent of the Supreme Court because many matters that come before them potentially implicate federal law. Accordingly, they still have some relationship with the Supreme Court and its decisions. Third, the Supreme Court itself has an interest in maintaining its own authority to review state decisions and using that to affect policy change on a broader scale. For instance, Justice O'Connor, writing for the majority in Michigan v. Long, argued that the Court would 
assume that decisions of state supreme courts implicated federal law unless explicitly stated otherwise in the opinion. ${ }^{1}$

Empirical research does not resolve these conflicting expectations. Although state supreme courts enjoy certain latitude, their decisions are still shaped by Supreme Court precedent (see Cannon 1973, 1974). For example, Hoekstra's (2005) study of minimum wage law from the early part of the $20^{\text {th }}$ century shows that Supreme Court decisions substantially influence the probability state courts overturn challenges to state laws. Conversely, other work on state supreme courts suggests that institutional arrangements, case facts, and judicial preferences are also influential. Brace and Hall have demonstrated that state level institutions affect the decisions of state supreme courts (Brace and Hall 1990, 1993, 1997; Hall and Brace 1989, 1992, 1994). Clearly state supreme court justices work in an environment with a wide array of legal and institutional pressures (see Langer 2002). We expect that these forces - both legal and electoral - will affect the choices made by state supreme court justices in search and seizure cases. Our goal here is to expand on these themes by systematically exploring how these state conditions predicate the influence of Supreme Court precedent.

\section{Theoretical Framework}

The use of Supreme Court precedent by state supreme courts is complicated by the difficulty state judges have in reconciling state and federal law. Previous studies of Supreme Court/Circuit Court of Appeals interactions relies in large part on principalagent theory to explain the dissemination of Supreme Court precedent among those courts (Songer, Segal, and Cameron 1994; Cameron, Segal, and Songer 2000; 
Westerland, Segal, Epstein, Comparato, and Cameron 2006). Yet this may not be the most appropriate lens through which to monitor the relationship between the Supreme Court and state supreme courts. Though the Supreme Court has substantial power to review state courts, the relationship is not strictly hierarchical for reasons discussed above. Unlike judges on lower federal courts, state supreme courts are also embedded in state political environments that include other actors with the ability to influence their decisions. Governors, state legislatures, and the public have means at their disposal to alter policy in response to the written decisions of state supreme courts, the most important of which is the ability to remove judicial decision-makers from office. It is those arrangements that constrain the decision making process of state supreme court justices further complicating their relationship with the Supreme Court.

Because state supreme court justices are motivated to retain their position, they behave in a manner to minimize the risk of removal. As a result, they must concern themselves not only with the probability that their decisions may be reviewed and overturned by the Supreme Court, but must also be mindful of the local political context. This is not to suggest that state supreme court justices are simply instruments of state level actors with the power to retain those judges, but it does have profound implications for understanding how state supreme courts make us of Supreme Court precedent. We wholly expect that other factors, such as their own policy goals, will affect their decisions. However, because most state justices do not enjoy life tenure we expect the structure of their seat retention incentives to also be influential.

This orientation focuses our attention on the institutional arrangements that determine how state justices maintain their position. While we consider it axiomatic that they wish 
to avoid reversal by the Supreme Court, local political pressures may create situations in which following such precedent might put them in jeopardy of staying on their court. Specifically, the fact that the states use different methods for retaining state supreme court justices leads us to expect that the constraints imposed by these institutional differences will generate different responses to Supreme Court precedent. They will behave in a risk averse manner, minimizing the negative electoral consequences of their decisions while in the pursuit of their most preferred policy outcome.

Related to this issue of risk avoidance is the question of monitoring. Most decisions of state supreme court justices are unknown to the electorate. For state supreme court justices the more relevant, and potentially harmful, monitoring comes from the state political elites. These actors (governor or legislature) are more likely to be aware of the decisions of the state supreme court, and whether their decisions have been reviewed and overturned by the Supreme Court. Because political elites are more likely to be interested in, and informed about, the actions of the state supreme court we expect them to exercise closer scrutiny of justices than will state electorates. Within systems that elect judges, we further expect those in competitive systems to more closely monitored than those in retention systems.

These local monitoring differences hold different implications for state judges. First, in elite retention systems the main impact of the Supreme Court ought to be through fact patterns and not policy. This is because elites have more clear power over state supreme court justices, as well as better knowledge of their decisions. Second, in electoral systems, monitoring by the electorate should be low enough that judges have considerable latitude in how to make decisions (see Baum 1983, 1987; Dubois 1979; 
Sheldon and Lovrich 1983). More importantly, the low level of monitoring implies that they should be relatively safe and secure as long as they do not engage in behavior that alerts the public. ${ }^{2}$ We conjecture that a prominent way for this to occur is by engaging in protracted contract with the Supreme Court because that is likely to draw the attention of the media and opinion leaders.

Finally, the presence of potential competitors in some electoral systems ought to also produce some variations in judicial behavior. Even as we expect judges in those systems to be risk averse and generally wanting to avoid conflict with the Supreme Court, the possibility of facing competition - even if rare - means that they must be in a position to defend their decisions to an electorate concerned with more than just judicial merit. Since the Supreme Court traditionally has more power to set a floor, rather than a ceiling, in civil liberties cases, that provides these justices with political cover when citing liberal precedent. Consequently, we expect conflict with the Supreme Court to produce responsiveness to liberal precedent, but not to conservative precedent. In merit systems, the absence of competitors to point out the policy impact of judicial decisions implies an opposite effect - all that matters is to avoid calling attention to oneself. As such, conflict with the Supreme Court ought to produce responsiveness to both liberal and conservative precedent.

Although the state supreme court justices' motivations, and the Supreme Court's limited control over state courts, should limit the impact of Supreme Court precedent on state decisions, we argue that monitoring by the Supreme Court still matters. What differs from the Court's monitoring of federal courts is that its impact depends upon the 
political position of the state court. When ignoring the Supreme Court benefits the lower court's ability to signal their quality to the appropriate decision makers at the state level, we wholly expect them to ignore precedent. However, there may be situations where conflict with the Court draws unwanted attention and increases the risk of retention for state justices, thus creating a situation where they may be more willing to follow precedent. The question, of course, is when monitoring by the Supreme Court interacts with local monitoring to create a situation in which they follow precedent.

\section{Data and Variables}

Sample. In order to test these hypotheses, we analyze a sample of state supreme court cases that cite orally argued search and seizure cases decided by the Supreme Court between the 1983 and 1993 terms. We choose to analyze search and seizure cases because 1.) the likelihood of progeny existing in every state is high, and 2.) it has remained a relatively constant part of the Supreme Court's docket. Additionally, using search and seizure cases allows us to test for judicial impact in a traditional area of state responsibility (Baum 1978).

We first identified all orally argued search and seizure cases decided by the Supreme Court between the 1983 and 1993 terms - a total of 63 cases. ${ }^{3}$ For each of these Supreme Court cases, we used Shepard's Citations to compile a list of every decision in a state court of last resort in which it was cited for the years 1983-1995. This creates a population of progeny from which we randomly selected 974 cases - approximately thirty-one percent of all state supreme court cases citing these Supreme Court decisions - 
on which to gather further data. These progeny serve as our primary unit of analysis. ${ }^{4}$ Using this approach provides a large number of relevant state supreme court cases and identifies those cases of most interest to our research questions - those that cite Supreme Court precedent.

Although expedient, this methodology has recognizable limits. First, this sampling approach potentially overstates the impact of Supreme Court precedent by not including cases which fail to cite precedent. The primary means of addressing this is by limiting our conclusions to the appropriate progeny, keeping in mind that a broader statement of the Court's impact on the states requires us to model the selection process. Second, state supreme courts cite Supreme Court precedent that they do not directly deal with in their own decision. For example, if a lower court disagrees with a specific decision of the Supreme Court, they may bury the reference to that offending precedent amongst a number of other cases cited in an attempt to evade the holding of that case. In other words, they may not be addressing cited precedent in any depth.

To address this second issue, we coded for the total number of citations in the progeny and the length of the citation string where the generating Supreme Court case was found. ${ }^{5}$ Over $70 \%$ of the progeny contain only one citation to a Supreme Court decision, and only two cases are cited in nearly $90 \%$ of the progeny. Our data also suggest that state courts do not "bury" references in a string of cases. In approximately $65 \%$ of the progeny, the Supreme Court precedent is cited alone, and it is joined by a

\footnotetext{
${ }^{14}$ Texas and Oklahoma have two courts that serve as the court of last resort, one for civil procedures and one for criminal matters. Since we were dealing with search and seizure cases, we only examined progeny in the Oklahoma Criminal Court of Appeals and the Texas Court of Criminal Appeals.
} 
second case in only $21 \%$ of the progeny. We take this as evidence that the Supreme Court precedents we use to generate our sample are central to the case under consideration by the progeny. We believe this to be fairly compelling evidence that state supreme court justices recognize the relevance of the Supreme Court precedent, rely on it in their opinions, and appear to make little effort to obfuscate the fact that it is pertinent to the case at hand. This makes us feel more confident that our data gathering approach yields a set of cases and measures that are germane to the issue of state supreme court compliance.

Variables. Following other work in the field, our dependent variable is a dichotomous measure of whether the state court ruled in favor of the government (coded “1”) or the individual (coded "0”). Our hypotheses point to three different types of independent variables that should affect this variable - measures of case facts, judicial political preferences, and institutional constraints. To evaluate the normative effects of Supreme Court precedent, we include a variable that captures the degree to which the factual circumstances of the state supreme court decisions mirror conditions determined as important in Supreme Court precedent writ large. Following Segal (1984), we first measure the presence of seven different facts in search and seizure cases. ${ }^{6}$ For each of these, the Supreme Court has previously established the validity of police searches in its presence. Our variable is a count of how many of these are present in the progeny case. The logic of this measure is straightforward - when a case before a state supreme court strongly overlaps with existing Supreme Court precedent, the likelihood that the state court upholds a search is higher. Including this measure allows us to better evaluate the 
political impact of cited precedent by controlling for both its normative effects and its usefulness to state court decision-makers.

We measure the political preferences of judicial actors in a manner similar to previous studies in the field. First, we do not explicitly measure the predilections of the Supreme Court. Between 1983 and 1993, the mean ideology score on the Supreme Court is always conservative, though it does shift slightly to the right in 1986 with Rehnquist replacing Burger as chief justice, and the appointment of Scalia to the Court. Because it is a relative constant throughout the course of our sample, it is not explicitly incorporated into our analyses. ${ }^{7}$ We do include a measure of the precedent's direction in order to gauge its policy impact (see Hoekstra 2005). This measure is coded one if the Supreme Court ruled in favor of the government and zero otherwise. Assuming that state courts mainly cite relevant precedent, then this variable should increase the likelihood of a similar decision at the state level, ceteris paribus, if it has an impact on the lower court (Hoekstra 2005). We measure the ideology of state supreme court justices using PAJID scores (Brace, Langer, and Hall 2000). Specifically, the variable is the median PAJID score for state supreme courts by year over the $1983-1995$ period. $^{8}$ This is an interval measure with a range from zero (highly conservative) to one hundred (highly liberal). ${ }^{9}$

Finally, our design includes measures of the institutional constraints faced by state supreme courts. Supreme Court monitoring is measured with two variables. The first is the importance of the case to the Supreme Court, measured as the number of search and seizure cases decided by the Supreme Court in the three years leading up to the state supreme court decision (Cameron, Segal, and Songer 2000). The second gauges conflict between the Supreme Court and the state supreme court by coding the number of times 
that the Supreme Court has reversed that state supreme court on any issue in the previous five years. State institutional constraints are measured with a trichotomous variable that distinguishes states with retention elections, competitive elections, and appointive systems. Information on state judicial retention systems comes from The Book of the States (2003).

Descriptive statistics for the independent variables are reported in Table 1. With these data we are able to evaluate our hypotheses about lower court decision-making in ways that have not yet been attempted. Unlike other studies, that focus on a relatively small number of cases in a single issue area for a few courts (see Beavers and Walz 1998; Beiser 1968; Cross and Tiller 1998; Dickson 1994; Gruhl 1981; Romans 1974; Smith and Tiller 2002), we are able to evaluate how all state supreme courts address decisions of the Supreme Court. In the following section, we discuss the results from these models.

[Table 1 about here]

\section{Levels of Impact}

Does the Supreme Court affect the direction of state supreme court decisions through precedent? As a first cut at this question, we look at the simplest - but most straightforward - piece of evidence. Table 2 shows the overall distribution of progeny by the direction of both the cited precedent and the state supreme court decision. If state supreme courts simply do what the Supreme Court suggests, we would expect all of the observations to fall into the two impact categories. On the other hand, if state supreme courts purposely (and unrealistically) do not follow the decisions of the Supreme Court, then the cases would fall into the remaining categories.

[Table 2 about here] 
There is at least partial evidence here that state supreme courts make decisions consistent with Supreme Court precedent. Eighty percent of the progeny cited Supreme Court precedent that favored government, essentially protecting the authority of the police to gather evidence. This is not surprising considering the fact that the Court was consistently conservative for the time period under examination, though it does suggest a certain amount of cross-level judicial impact. Also consistent with legal depictions of judicial hierarchy, $55 \%$ of all progeny decided on behalf of the same party as the Supreme Court precedent it cited. This level of judicial consensus is a testimony to the centrifugal pull of the decisions of the Supreme Court.

However, there is also substantial evidence that state supreme courts are making decisions based on other factors. In $45 \%$ of the cases, the state-level decision favors a different actor than the cited Supreme Court precedent, a non-negligible proportion of cases. Among the four possible combinations, the second most frequent category $(33 \%)$ occurs when states restrict the government's authority while citing a Supreme Court case that does the opposite. The high frequency of this behavior probably reflects, in part, liberal state courts distinguishing themselves from the conservative Supreme Court of this era. However, it is also undoubtedly reflects the fact that the Supreme Court can set a floor, but not a ceiling, on individual liberties. Buttressing this point is that in only $12 \%$ of the cases does the state favor the government actor while citing a liberal Supreme Court case.

Are these patterns related to variations in state context? Table 3 shows the distribution of cases and outcomes in the fifty states. As this table makes clear, there is substantial variation in the potential impact of Supreme Court precedent on state 
behavior, though the small sample sizes require us to view the point estimates with skepticism. Some states, such as Delaware, Iowa, Maine, and Mississippi, cite precedent that is pro-government and generally make the same decision. Other states, such as California and Pennsylvania, consistently rule in favor of individuals while citing progovernment precedent. In still other states like Idaho and Virginia, progeny are more evenly distributed in each of the four categories. The key point is that there is substantial variation across the states in the relationship between precedent and state supreme court decisions.

\section{[Table 3 about here]}

These data hold important insights into the working of our judicial system. Importantly, there is evidence that the Supreme Court can effectively set a floor through precedent, evidenced by the relatively infrequent appearance of pro-government decisions citing pro-individual precedent. But legalistic explanations of the judicial hierarchy do not seem capable of explaining state-by-state variations. If Supreme Court precedent has strong normative value we should not observe strong and systematic levels of variation across the states. Conversely, if the state courts are fundamentally free from Supreme Court influences, we would expect a random distribution of cases in the four categories across states. Instead, we see strong cross-state differences that are at least superficially related to the political factors. For example, the patterns of impact in Table 3 are consistent with the idea of conflict between a conservative Supreme Court and at least a handful of more liberal state courts that choose to extend individual liberties further. Although these results are interesting, they do not explain - under what political and institutional circumstances Supreme Court precedent influences state supreme court 
decisions.

\section{Predicting the Outcomes of Progeny}

The next step in our analysis is to model the outcomes of individual progeny as a function of case characteristics, judicial political preferences, and institutional constraints. Since our dependent variable is dichotomous $(1=$ decision in favor of state, $0=$ decision in favor of individual), we use a logit model to estimate the impact of each independent variable on the probability that the state supreme court rules in favor of the government. To account for possible dependencies among cases decided in the same state, we employ clustered standard errors by state. Given that our theoretical framework predicts that state judicial institutions determine its responsiveness to policy influence of Supreme Court precedent, we separate our data into different samples by judicial retention method - Elite Retention, Competitive Election, and Retention (Merit) Election. The results are reported in Table 4.

[Table 4 about here]

Looking the three sets of results, some interesting patterns emerge. In all three systems, case facts have a statistically significant and positive effect. Simply stated, state court decisions in cases that overlap significantly with fact patterns identified by the Supreme Court as legitimate situations for warrantless searches are more likely to favor the government. This result is entirely consistent with the normative view of the judicial hierarchy - that justices are attentive to the facts of the case before them. Of note is that the size of the case facts variables is twice as large in the Elite Selection model as it is in the Competitive Election model; it is 50\% larger than the coefficient in the Retention Election model. Interestingly, the results also show that court ideology is only 
statistically significant in merit systems. In both the Elite Selection and Competitive Election models, the coefficient is statistically insignificant.

More central to the questions identified in this paper are the coefficients associated with the direction of cited Supreme Court precedent, the level of conflict between the Supreme Court and state court, and the interaction of these two variables. Because of the interaction term, the standard errors reported in the table do not provide us with complete information on the significance of these three variables (Friedrich 1982). Nevertheless, there are some interesting differences between the results in different institutional settings. Most importantly, in elite selection systems, the baseline impact of Supreme Court precedent is higher than it is in either of the electoral systems. What this means is that, in the absence of any reversals there is a greater tendency toward impact in the elite systems than in electoral systems. ${ }^{10}$ Conversely, in electoral systems the impact of precedent is more clearly dependant upon the actions of the Supreme Court, a fact reflected in the somewhat larger coefficients associated with frequency of reversal and the interaction term.

While we reserve our full discussion of these results for the next section, the statistical results provide the foundation for some interesting conclusions. Foremost among them is that, no matter the institutional or political circumstances faced by state justices, they respond to the broad normative constraints established by Supreme Court precedent. This is consistent with arguments that 1) the Supreme Court sets a floor for the states on civil liberties issues, and; 2) legal norms are important for establishing coherency throughout the judiciary. Beyond this, we find that political factors still matter a great deal, though the manner and extent to which they matter depends upon the local 
institutions for selecting and retaining justices. In particular, it appears that judges in states with electoral systems are more responsive to the specific political predilections ensconced in precedent when they have been susceptible to the higher courts intervention in recent years.

\section{Substantive Effects}

To get a better understanding of how Supreme Court precedent impacts state decisions in different settings, we show the impact of our variables on the probability that the state court favors the government in its decision. Using the coefficient values from Table 4 and holding all other variables at their means (not including interaction coefficients), we first focus on the effects of frequency of reversal. ${ }^{11}$ In doing so, we compute probabilities for courts that are relatively liberal, moderate, and conservative. ${ }^{12}$ Finally, we engage in this exercise for Supreme Court precedent that is both proindividual (labeled as "Liberal" in the graph) and pro-government (labeled as "Conservative") Supreme Court precedent.

Figure 1 shows the impact of frequency of reversal in elite systems. Two things stand out in this graph. Foremost is that the impact of frequency of reversal is to always reduce the probability that a state wins. Although this is not inconsistent with our theoretical expectations, we can offer no clear explanation within our framework either. It would seem that these courts see all conflict with the Supreme Court as encouraging them to pay attention to the floor, but we cannot convincingly demonstrate the veracity of this claim. Additionally, we see that judicial ideology has next-to-no impact on state judicial decisions in these systems. Indeed, the lines for conservative, moderate, and liberal courts are indistinguishable. 
[Figure 1 about here]

Figure 2 repeats this exercise for states that use competitive elections. Regardless of the direction of the cited Supreme Court precedent, conservative state courts are always more likely to rule in favor of the government and liberal courts in favor of individuals. This confirms the importance of state judicial institutions for creating situations in which judicial actors can consume their own ideological preferences, though the effect is not very strong.

[Figure 2 about here]

What we see in these graphs is a striking difference based upon the direction of the cited Supreme Court precedent. When it is conservative - that is, it establishes a ceiling - state courts typically have at least a $70 \%$ probability of also making a conservative decision. A similar picture emerges when state courts cite liberal Supreme Court decisions - those that establish a floor. Keeping in mind that these state courts are susceptible to close monitoring by state political actors, the states are less likely to win if they have been reversed recently. Regardless of the ideology of the state supreme court court's ideology, the probability of a pro-government decision is around $70 \%$ If we assume that governors and legislatures do not want high profile criminal cases to be overturned, this seems like a reasonable result. However, as the Supreme Court becomes more involved through overturning the states, it can effectively enforce its floor. For states that have been overturned five or more times, the probability of a pro-government decision drops below the $50 \%$ line for both liberal and conservative precedent.

Also of interest here is that, despite the fact that state court political preferences are substantively important, the Supreme Court is still capable of encouraging lower courts to 
comply with its pro-individual decisions. There is more resistance in these systems to conservative precedent, witnessed by the fact that state courts regardless of ideology do not alter their behavior in the face of numerous reversals. This is entirely in keeping with the idea that the federal constitution sets a floor for individual rights and that states are free to afford greater protections. When justices in competitive election states cite liberal Supreme Court precedent the probability of the state winning is over $80 \%$, but as they are increasingly reversed by the Supreme Court, the states probability of winning drops quickly.

In Figure 3, we present the results of the impact of frequency of reversal on state judicial behavior in merit retention systems. Here the substantive results are most striking. In these states, when justices cite liberal decisions of the Supreme Court, the state has a near $80 \%$ probability of winning, but by five reversals, that probability has declined below $20 \%$. When citing conservative precedent, regardless of state judicial ideology, the justices are more likely to vote conservatively as the frequency of reversal by the Supreme Court increases. These results are clear examples of the effect of judicial ideology exerting a substantive impact on the outcome - we see justices instrumentally responding to cited precedent on the bases of how frequently they conflict with the Supreme Court. This is consistent with our arguments about risk aversion.

[Figure 3 about here]

Lastly, in Figure 4, we present evidence of the substantive importance of case facts on state supreme court behavior. Traditional concepts of precedent suggest that as the case facts in the extant case before a justice more closely resemble those in a previously decided case, the influence of that precedent increases. Here we see clear evidence that 
the precedent is not treated similarly by justices across retention methods, further confirming our earlier claims that the normative and political impact of precedent depends upon the state judicial institutions.

[Figure 4 about here]

In elite retention systems, the power of precedent is evident. When citing liberal decisions of the Supreme Court the probability that the state wins rises at approximately the same rate as the number of case facts increases regardless of the rate of reversal, suggesting that justices in those states are responding, not to the 'sanction' being meted by the Supreme Court, but are, in fact, responding to the facts of the case. ${ }^{13}$ That changes slightly for justices in competitive election states where recent reversal by the Supreme Court does appear to exert an influence on the probability of the state winning. However, the most striking findings arise when viewing the impact of case facts in merit retention states. Here the effect of Supreme Court reversals on the state is substantial. Where the state court has not been reversed the probability of the state winning is close to $50 \%$, increasing to over $90 \%$ by the time they reach six similar case facts. Conversely, where the state has been reversed recently, the probability of the state winning is less than $20 \%$, but that increases to just over $50 \%$ of the time when six facts are present. This provides substantial support for the conclusion that in merit retention states, justices are behaving in a risk averse manner to achieve their policy goals within the constraints placed on them by the Supreme Court.

\section{Conclusion}

The results presented here have important theoretical and substantive implications for understanding the relationship between the Supreme Court and state supreme courts, but 
also for interpreting the importance of judicial retention methods and compliance with precedent. Our results provide evidence that runs counter to the arguments forwarded by policy makers interested in reforming state judicial retention methods. Justices in elite retention systems respond to Supreme Court precedent most like how traditional legal scholarship suggests that lower court judges should behave - precedent serves an instructional purpose and state supreme court justices in those states evince a clear pattern of following Supreme Court precedent regardless of ideology. In effect, despite being chosen and retained by the legislature or governor of the state, these judges behave most like we expect judges to behave.

State supreme court justices in competitive and merit retention states behave quite differently, with (surprisingly) merit retention justices resisting Supreme Court precedent and only grudgingly altering their decisions to conform to precedent when they are reversed by the Supreme Court. This runs counter to arguments suggesting that merit systems produce 'better' judges. If better means those less able (or willing) to vote their policy preferences, regardless of existing Supreme Court precedent, then the results here cast some doubt on that perspective. This research points out the complex relationship between state supreme courts and the Supreme Court and illuminates the importance of institutional arrangements in understanding the dissemination of precedent to the states. 


\section{References}

Baum, Lawrence. (1978). Lower Court Response to Supreme Court Decisions:

Reconsidering a Negative Picture. Justice System Journal, 3, 208-219.

- (1983). The Electoral Fates of Incumbent Judges in the Ohio Court of

Common Pleas. Judicature, 66, 42-50.

. (1987). Explaining the Vote in Judicial Elections: The 1984 Ohio Supreme

Court Elections. Western Political Quarterly, 40, 361-371.

Beavers, Staci L., and Jeffrey S. Walz. (1998). Modeling Judicial Federalism: Predictors

of State Court Protections of Defendants’ Rights Under State Constitutions, 1969-

1989. Publius, 28, 43-59.

Beiser, Edward N. (1968). A Comparative Analysis of State and Federal Judicial

Behavior: The Reapportionment Cases. American Political Science Review, 62, 788795.

Benesh, Sarah C., and Malia Reddick. (2001). Overruled: An Event History Analysis of Lower Court Reaction to Supreme Court Alteration of Precedent. Journal of Politics, 64, 534- 550 .

Brace, Paul, and Melinda Gann-Hall. (1990). Neo-Institutionalism and Dissent in State Supreme Courts. Journal of Politics, 52, 54-70.

. (1993). Integrated Models of Judicial Dissent. Journal of Politics, 55, 914-

935.

- (1997). The Interplay of Preferences, Case Facts, Context, and Rules in the Politics of Judicial Choice. Journal of Politics, 59, 1206-1231. 
Brace, Paul, Laura Langer, and Melinda Gann-Hall. (2000). Measuring the Preferences of State Supreme Court Judges. Journal of Politics, 62, 387-413.

Cameron, Charles, Jeffrey Segal, and Donald R. Songer. (2000). Strategic Auditing in a Political Hierarchy: An Informational Model of the Supreme Court's Certiorari Decisions. American Political Science Review, 94, 101-115.

Canon, Bradley. 1973. Reactions of State Supreme Courts to a Supreme Court Civil Liberties Decision. Law and Society Review, 8, 109-134. . (1974). Organizational Contumacy in the Transmission of Judicial Policies: the Mapp, Escobedo, Miranda, and Gault, Cases. Villanova Law Review, 20, 50-79. Council of State Government. (2003). The Book of the States, Vol. 35. Lexington, KY: Council of State Government.

Cross, Frank. (2005). Appellate Court Adherence to Precedent. Journal of Empirical Legal Studies, 2, 369-405.

Cross, Frank, and Emerson H. Tiller. (1998). Judicial Partisanship and Obedience to Legal Doctrine: Whistleblowing on the Federal Courts of Appeals. Yale Law Journal, 107, 2155-2176.

Dickson, Del. (1994). State Court Defiance and the Limits of Supreme Court Authority: Williams v. Georgia. Yale Law Journal, 103, 1423-1481.

Dubois, Philip. (1979). Voter Turnout in State Judicial Elections: An Analysis of the Tail on the Electoral Kite. Journal of Politics, 41, 865-887.

Emmert, Craig F. (1992). An Integrated Case-Related Model of Judicial Decisionmaking: Explaining State Supreme Court Decisions in Judicial Review Cases. Journal of Politics, 54, 543-552. 
Emmert, Craig F., and Carol Ann Traut. (1994). The California Supreme Court and the Death Penalty. American Politics Quarterly, 22, 41-61.

Epstein, Lee, and Jack Knight. (2000). Field Essay: Toward a Strategic Revolution in Judicial Politics: A Look Back, A Look Ahead. Political Research Quarterly, 53, $625-661$.

Friedrich, Robert. (1982). In Defense of Multiplicative Terms in Multiple Regression Models. American Journal of Political Science, 26, 797-833.

George, Tracey E., and Lee Epstein. (1992). On the Nature of Supreme Court Decision Making. American Political Science Review, 86, 323-327.

Griffin, Kenyon N. And Michael J. Horan. (1993). Patterns of Voting Behavior in Judicial Retention Elections for State Supreme Court Justices in Wyoming. Judicature, 67, 68-77.

Gruhl, John. (1980). The Supreme Court's Impact on the Law of Libel: Compliance by Lower Federal Courts. Western Political Quarterly, 33, 502-519.

. (1981). State Supreme Courts and the U.S. Supreme Court's Post Miranda Rulings. Journal of Law and Criminology, 72, 886-913.

Hall, Melinda Gann, and Paul Brace. (1989). Order in the Courts: A Neo-Institutional Approach to Judicial Consensus. Western Political Quarterly, 42, 391-407. . (1992). Toward an Integrated Model of Judicial Voting Behavior. American Politics Quarterly, 20, 147-168. 
. (1994). The Vicissitudes of Death by Decree: Forces Influencing Capital

Punishment Decision Making in State Supreme Courts. Social Science Quarterly, 75, $136-151$.

Hansford, Thomas G., and James F. Spriggs II. (2006). The Politics of Precedent on the U.S. Supreme Court. Princeton, NJ: Princeton University Press.

Hoekstra, Valerie. (2005). Competing Constraints: State Court Responses to Supreme Court Decisions and Legislation on Wages and Hours. Political Research Quarterly, $58,317-328$.

Johnson, Charles A. (1979). Lower Court Reactions to Supreme Court Decisions: A quantitative Examination. American Journal of Political Science, 23, 792-804.

Klein, David E. and Robert J. Hume. (2003). Fear of Reversal as an Explanation of Lower Court Compliance. Law and Society Review, 37, 579-606.

Knight, Jack, and Lee Epstein. (1996). The Norm of Stare Decisis. American Journal of Political Science, 40, 1018-1035.

Landes, William M., and Richard A. Posner. (1976). Legal Precedent: A Theoretical and Empirical Analysis. Journal of Law and Economics, 19, 249-307.

Langer, Laura. (2002). Judicial Review in State Supreme Courts. Albany, NY: State University of New York Press.

Maltzman, Forrest, James F. Spriggs, and Paul J. Wahlbeck. (2000). Crafting Law on the Supreme Court: The Collegial Game. Cambridge: Cambridge University Press. Michigan v. Long. 1983. 463 U.S. 1032. 
Romans, Neil. (1974) The Role of State Supreme Courts in Judicial Policy Making: Escobedo, Miranda and the Use of Judicial Impact Analysis. Western Political Quarterly, 27, 38-59.

Segal, Jeffrey. (1984). Predicting Supreme Court Cases Probabilistically: The Search and Seizure Cases (1962-1981). American Political Science Review, 78, 891-900. . (1986). Supreme Court Justices as Human Decision Makers: An IndividualLevel Analysis of the Search and Seizure Cases. Journal of Politics, 47, 938-955. Segal, Jeffrey A., and Harold J. Spaeth. (2002). The Supreme Court and the Attitudinal Model Revisited. Cambridge: Cambridge University Press.

Sheldon, Charles H., and Nicholas P. Lovrich. (1983). Knowledge and Judicial Voting: The Oregon and Washington Experience. Judicature, 67, 234-245.

Smith, Joseph L., and Emerson H. Tiller. (2002). The Strategy of Judging: Evidence from Administrative Law. The Journal of Legal Studies, 31, 61-82.

Songer, Donald R., Jeffrey Segal, and Charles Cameron. (1994). The Hierarchy of Justice: Testing a Principal-Agent Model of Supreme Court-Circuit Court Interactions. American Journal of Political Science, 38, 673-696.

Spaeth, Harold J. (2007). The Original United States Supreme Court Judicial Database, 1953-2005 Terms. http://www.as.uky.edu/polisci/ulmerproject/sctdata.htm.

Tarr, G. Alan. (1977). Judicial Impact and State Supreme Courts. Lexington, Mass: Lexington Books.

Wahlbeck, Paul J. (1997). The Life of the Law: Judicial Politics and Legal Change. Journal of Politics, 59, 778-802. 
Wasby, Stephen L. (1970). The Impact of the United States Supreme Court: Some Perspectives. Homewood, IL: Dorsey Press.

Westerland, Chad, Jeffrey A. Segal, Lee Epstein, Scott Comparato, and Charles Cameron. (2006, April). Lower Court Defiance of (Compliance with) the U.S. Supreme Court. Paper presented at the annual meeting of the Midwest Political Science Association, Chicago, IL. 
Table 1. Descriptive Statistics. This table shows the mean, standard deviation, range, and number of observations for the main variables in the progeny-level dataset.

\begin{tabular}{|c|c|c|c|c|c|}
\hline Variable & Mean & $\begin{array}{c}\text { Standard } \\
\text { Deviation }\end{array}$ & Minimum & Maximum & $\mathbf{N}$ \\
\hline $\begin{array}{l}\text { Direction of } \\
\text { State Court } \\
\text { Decision }\end{array}$ & 0.59 & 0.49 & 0 & 1 & 959 \\
\hline $\begin{array}{l}\text { Direction of } \\
\text { Supreme } \\
\text { Court } \\
\text { Precedent }\end{array}$ & 0.80 & 0.40 & 0 & 1 & 974 \\
\hline $\begin{array}{l}\text { Mean PAJID } \\
\text { Score of } \\
\text { State Court }\end{array}$ & 49.36 & 19.50 & 8.18 & 85.98 & 974 \\
\hline $\begin{array}{l}\text { Frequency } \\
\text { of State } \\
\text { Supreme } \\
\text { Court } \\
\text { Reversal }\end{array}$ & 1.99 & 2.01 & 0 & 9 & 973 \\
\hline $\begin{array}{l}\text { Salience of } \\
\text { Search and } \\
\text { Seizure }\end{array}$ & 18.14 & 8.29 & 2 & 32 & 972 \\
\hline $\begin{array}{l}\text { Electoral } \\
\text { Method of } \\
\text { Retention }\end{array}$ & 0.74 & 0.44 & 0 & 1 & 974 \\
\hline Case Facts & 2.70 & 0.98 & 0 & 6 & 758 \\
\hline
\end{tabular}


Table 2. State Supreme Court Compliance with Supreme Court Precedent, 1983-

1995. This table displays the proportion of decisions from state courts of last resort that are decided consistent with the Supreme Court case they cite. The results show that for the 1983-1995 time period, the two most frequent outcomes were pro-government consistency and pro-individual inconsistency.

\begin{tabular}{lllr}
\hline \hline State Decision & U.S. Supreme Court Decision & Label & Percent \\
\hline Favor Government & Favor Government & Pro-Government & $47 \%$ \\
& & Impact & $(452)$ \\
Favor Government & Favor Individual & Pro-Government & $12 \%$ \\
& & Non-impact & $(118)$ \\
& & & \\
Favor Individual & Favor Government & Pro-Individual Non- & $33 \%$ \\
& & impact & $(316)$ \\
Favor Individual & Favor Individual & & $8 \%$ \\
& & Pro-Individual & $(73)$ \\
\hline \hline
\end{tabular}


Table 3. Impact in the States. This table shows the wide variation in treatment of

Supreme Court progeny across the states.

\begin{tabular}{|c|c|c|c|c|c|}
\hline State Name & $\begin{array}{r}\text { Pro-State } \\
\text { Impact } \\
\end{array}$ & $\begin{array}{r}\text { Pro-Individual } \\
\text { Impact }\end{array}$ & $\begin{array}{r}\text { Pro-State } \\
\text { Non-impact } \\
\end{array}$ & $\begin{array}{r}\text { Pro-Individual } \\
\text { Non-impact }\end{array}$ & $\begin{array}{r}\text { Number of } \\
\text { Progeny }\end{array}$ \\
\hline Alaska & $0 \%$ & $0 \%$ & $0 \%$ & $100 \%$ & 1 \\
\hline Alabama & $64 \%$ & $0 \%$ & $9 \%$ & $27 \%$ & 11 \\
\hline Arkansas & $63 \%$ & $0 \%$ & $8 \%$ & $29 \%$ & 24 \\
\hline Arizona & $67 \%$ & $8 \%$ & $8 \%$ & $17 \%$ & 12 \\
\hline California & $33 \%$ & $12 \%$ & $12 \%$ & $42 \%$ & 33 \\
\hline Colorado & $32 \%$ & $16 \%$ & $10 \%$ & $42 \%$ & 50 \\
\hline Connecticut & $47 \%$ & $11 \%$ & $19 \%$ & $23 \%$ & 47 \\
\hline Delaware & $67 \%$ & $4 \%$ & $8 \%$ & $21 \%$ & 24 \\
\hline Florida & $43 \%$ & $9 \%$ & $5 \%$ & $43 \%$ & 21 \\
\hline Georgia & $40 \%$ & $0 \%$ & $10 \%$ & $50 \%$ & 10 \\
\hline Hawaii & $0 \%$ & $11 \%$ & $11 \%$ & $78 \%$ & 9 \\
\hline Iowa & $81 \%$ & $6 \%$ & $0 \%$ & $13 \%$ & 16 \\
\hline Idaho & $40 \%$ & $5 \%$ & $30 \%$ & $25 \%$ & 20 \\
\hline Illinois & $50 \%$ & $9 \%$ & $9 \%$ & $32 \%$ & 22 \\
\hline Indiana & $37 \%$ & $10 \%$ & $21 \%$ & $32 \%$ & 19 \\
\hline Kansas & $65 \%$ & $6 \%$ & $6 \%$ & $23 \%$ & 17 \\
\hline Kentucky & $67 \%$ & $0 \%$ & $0 \%$ & $33 \%$ & 6 \\
\hline Louisiana & $50 \%$ & $6 \%$ & $13 \%$ & $31 \%$ & 16 \\
\hline Massachusetts & $51 \%$ & $3 \%$ & $14 \%$ & $32 \%$ & 37 \\
\hline Maryland & $46 \%$ & $8 \%$ & $0 \%$ & $46 \%$ & 24 \\
\hline Maine & $69 \%$ & $6 \%$ & $13 \%$ & $13 \%$ & 16 \\
\hline Michigan & $46 \%$ & $8 \%$ & $8 \%$ & $38 \%$ & 13 \\
\hline Minnesota & $40 \%$ & $10 \%$ & $33 \%$ & $17 \%$ & 30 \\
\hline Missouri & $53 \%$ & $10 \%$ & $5 \%$ & $32 \%$ & 19 \\
\hline Mississippi & $65 \%$ & $8 \%$ & $4 \%$ & $23 \%$ & 26 \\
\hline Montana & $65 \%$ & $0 \%$ & $5 \%$ & $30 \%$ & 20 \\
\hline North Carolina & $57 \%$ & $0 \%$ & $0 \%$ & $43 \%$ & 21 \\
\hline North Dakota & $45 \%$ & $9 \%$ & $0 \%$ & $45 \%$ & 22 \\
\hline Nebraska & $46 \%$ & $6 \%$ & $26 \%$ & $23 \%$ & 35 \\
\hline New Hampshire & $32 \%$ & $5 \%$ & $26 \%$ & $37 \%$ & 19 \\
\hline New Jersey & $40 \%$ & $13 \%$ & $13 \%$ & $33 \%$ & 15 \\
\hline New Mexico & $14 \%$ & $0 \%$ & $43 \%$ & $43 \%$ & 7 \\
\hline Nevada & $80 \%$ & $20 \%$ & $0 \%$ & $0 \%$ & 5 \\
\hline New York & $35 \%$ & $15 \%$ & $8 \%$ & $42 \%$ & 26 \\
\hline Ohio & $57 \%$ & $0 \%$ & $14 \%$ & $29 \%$ & 14 \\
\hline Oklahoma & $41 \%$ & $18 \%$ & $18 \%$ & $23 \%$ & 17 \\
\hline Oregon & $60 \%$ & $0 \%$ & $13 \%$ & $27 \%$ & 15 \\
\hline Pennsylvania & $23 \%$ & $4 \%$ & $4 \%$ & $69 \%$ & 26 \\
\hline Rhode Island & $47 \%$ & $12 \%$ & $12 \%$ & $29 \%$ & 17 \\
\hline South Carolina & $50 \%$ & $17 \%$ & $0 \%$ & $33 \%$ & 6 \\
\hline South Dakota & $44 \%$ & $0 \%$ & $33 \%$ & $22 \%$ & 9 \\
\hline Tennessee & $14 \%$ & $0 \%$ & $14 \%$ & $71 \%$ & 7 \\
\hline Texas & $38 \%$ & $10 \%$ & $8 \%$ & $44 \%$ & 39 \\
\hline Utah & $40 \%$ & $13 \%$ & $7 \%$ & $40 \%$ & 15 \\
\hline Virginia & $50 \%$ & $20 \%$ & $20 \%$ & $10 \%$ & 10 \\
\hline Vermont & $60 \%$ & $0 \%$ & $13 \%$ & $27 \%$ & 15 \\
\hline Washington & $44 \%$ & $11 \%$ & $22 \%$ & $22 \%$ & 18 \\
\hline Wisconsin & $70 \%$ & $0 \%$ & $17 \%$ & $13 \%$ & 23 \\
\hline West Virginia & $28 \%$ & $11 \%$ & $6 \%$ & $56 \%$ & 18 \\
\hline Wyoming & $53 \%$ & $0 \%$ & $18 \%$ & $29 \%$ & 17 \\
\hline Total & $47 \%$ & $8 \%$ & $12 \%$ & $33 \%$ & 959 \\
\hline
\end{tabular}


Table 4. Models of State Judicial Decision-Making Across Institutional Contexts.

These logit coefficients show the effect of political and legal variables on state judicial decisions across the three types of selection systems used in American states.

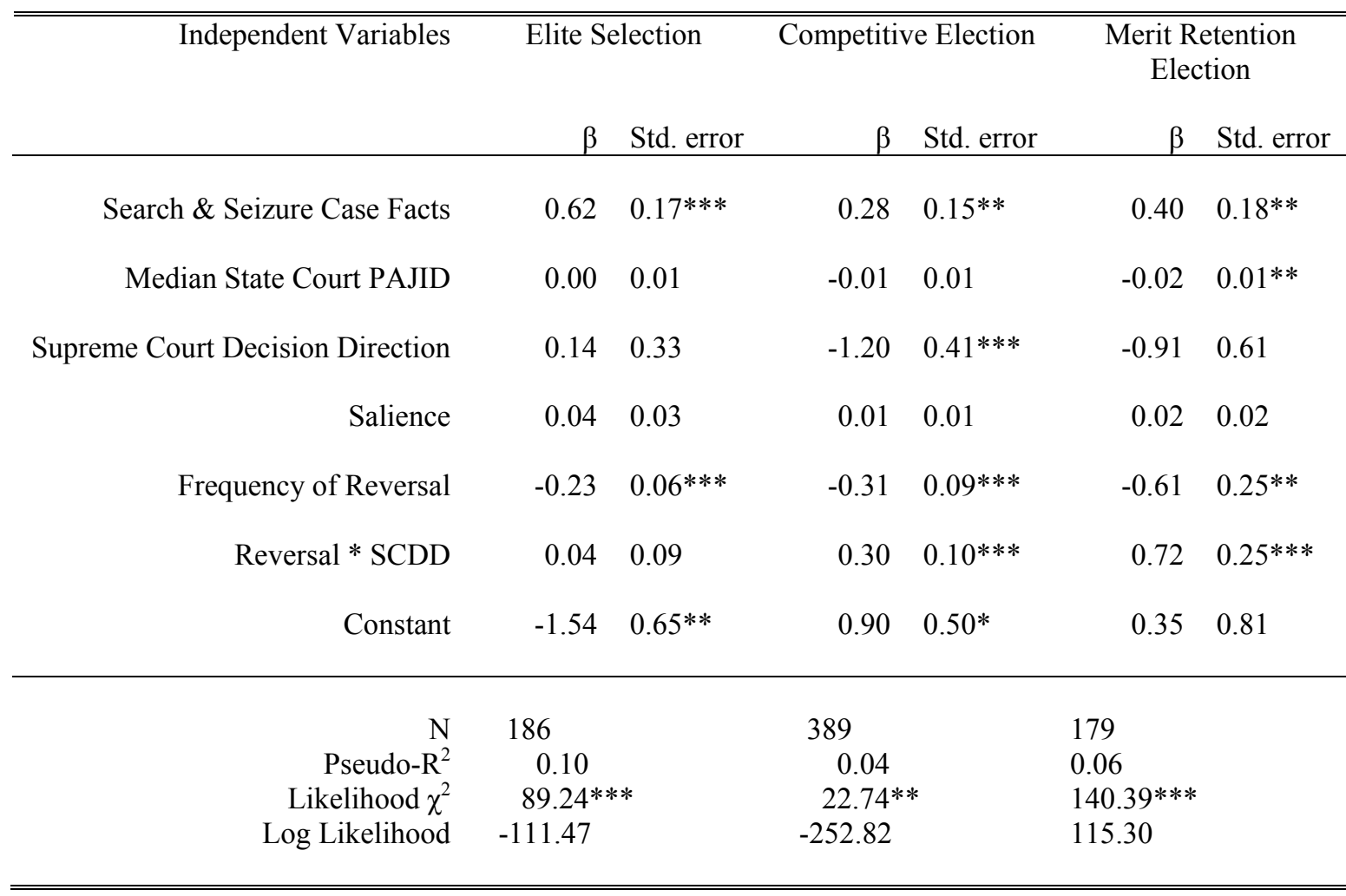

$* * * \mathrm{p}<.01$, two-tailed test $\quad * * \mathrm{p}<.05$, two-tailed test $\quad *_{\mathrm{p}}<.10$, two-tailed test


Figure 1. Impact of Frequency of Reversal, State Court Ideology, and the Direction of Supreme Court Precedent in Elite Selection Systems.

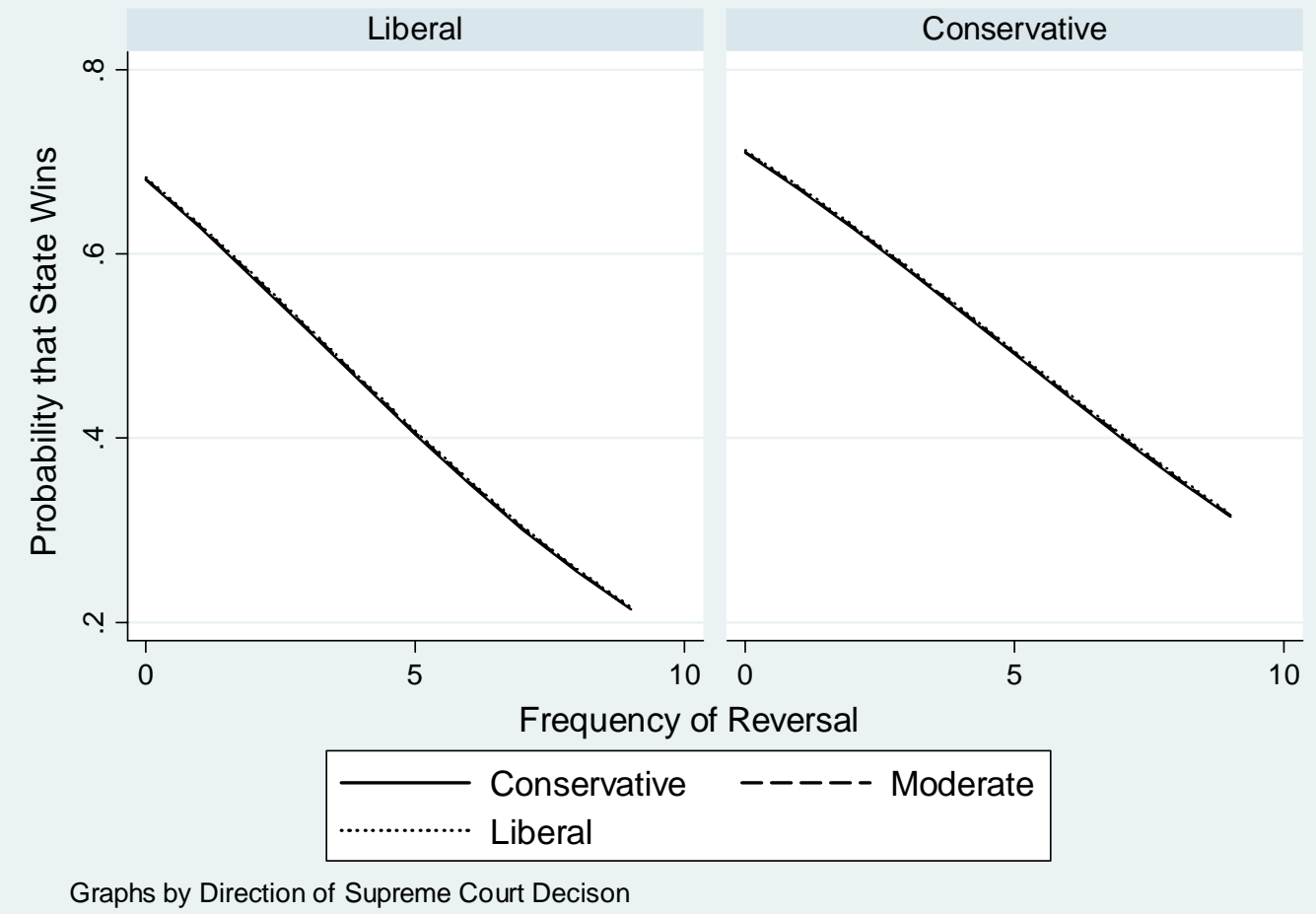


Figure 2. Impact of Frequency of Reversal, State Court Ideology, and the Direction of Supreme Court Precedent in Competitive Electoral Systems.

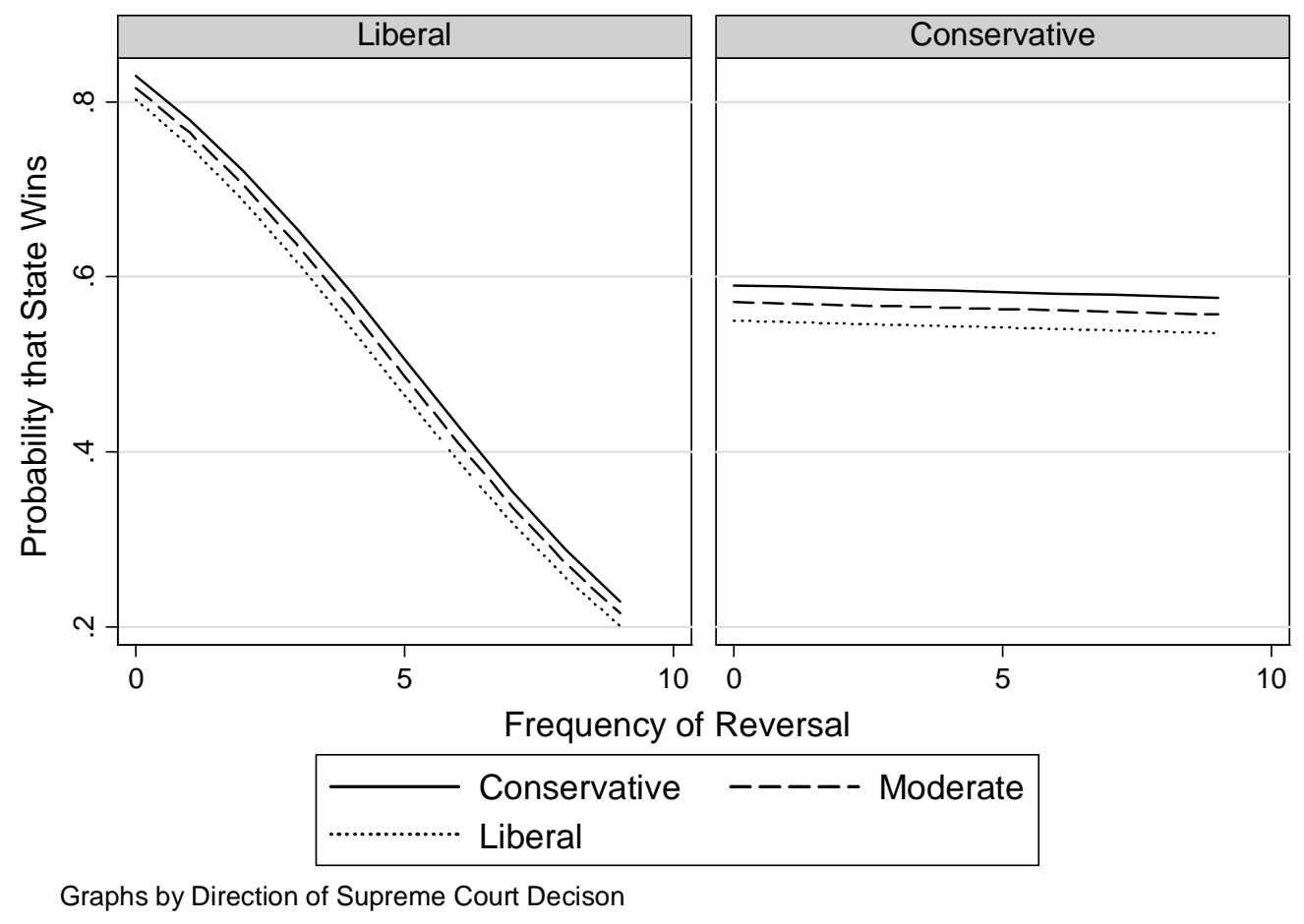


Figure 3. Impact of Frequency of Reversal, State Court Ideology, and the Direction of Supreme Court Precedent in Retention Systems.

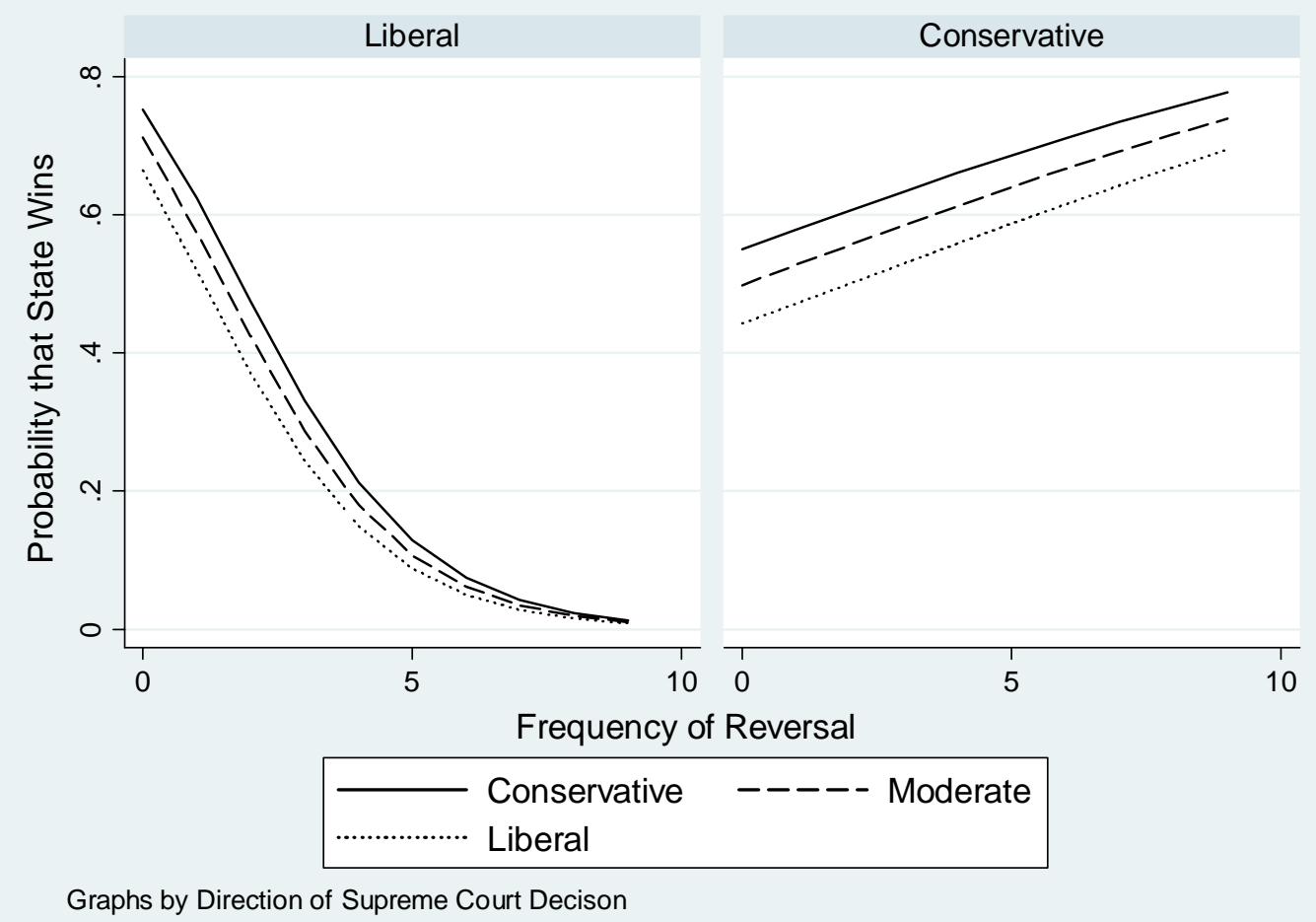


Figure 4. Impact of Case Facts, Frequency of Reversal, and State Judicial Institutions for Liberal Supreme Court Precedent.

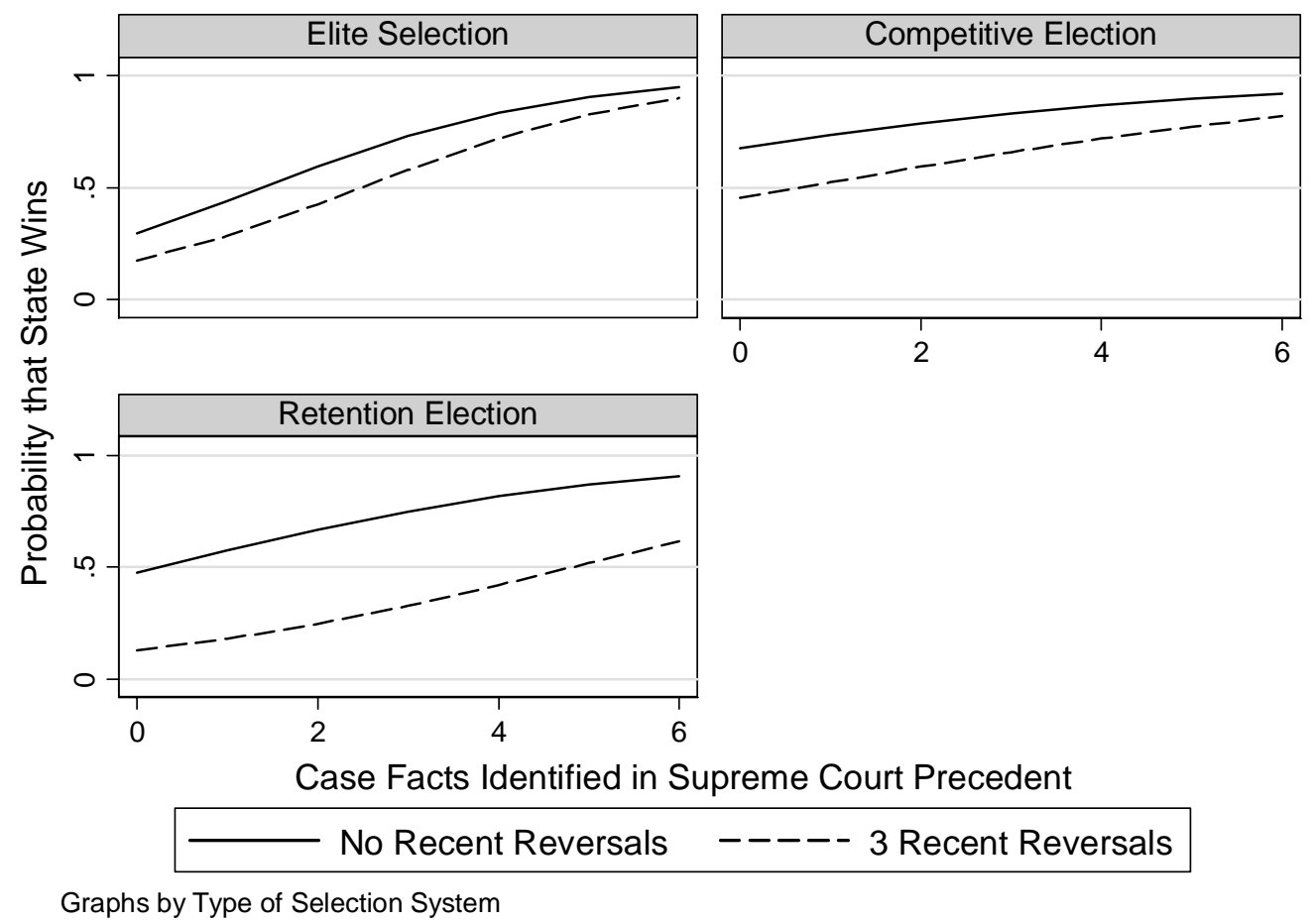




\section{Appendix A}

\section{Sampling State Supreme Court Progeny}

Sampling Procedure. The unit of analysis in our dataset is state supreme court progeny. To gather these data, we developed a three step process for identifying a representative sample of state supreme court progeny. First, we compiled a list of all orally-argued search and seizure cases that were decided upon the by Supreme Court from 1983-1993. We developed this list using the issue area codes and United States Identification Numbers in the United States Supreme Court Database. The temporal restriction is somewhat arbitrary, but was necessary in order to make our data collection effort manageable. This produced a list of sixty three different Supreme Court cases.

The second step was to Shepardize these Supreme Court cases. ${ }^{14}$ This generated a list that contained 4859 state supreme court decisions extending from 1983 to April 2002. Because the ideology scores for state justices only extends to 1995 (Brace, Langer, and Hall 2000), we dropped all state progeny decided after 1995. Eliminating these cases left us with a sampling frame of state citations with 3339 observations. Each Supreme Court case yielded an average of 53 progeny, though there was a fair amount of diversity in the distribution $\left(s^{2}=84.6\right)$ and the distribution is fairly skewed (median $\left.=30\right)$.

The third step was to draw a random number to each of these progeny. We did this by assigning each observation a unique number from a uniform distribution that ranged from zero to one, with mean equal to .5 . We then ordered the cases according to their randomly assigned number and drew the first sixteen percent for our sample. ${ }^{15}$ This yielded a sample of 1020 cases. For each of these progeny, we collected data on the independent and dependent variables described in the paper. After accounting for a

\footnotetext{
${ }^{15}$ Note that this is a "sampling without replacement" procedure.
} 
previously unidentified error in the sampling frame (a Supreme Court case decided prior to 1983 slipped into our frame) and missing data, we were left with an effective sample of approximately 974 observations.

Progeny Sample Quality. To assess the quality of our sample, we engaged in some post-hoc examination of the data. First, if our procedure produced an accurate representation of search and seizure progeny, we expected to find that the state supreme court cases would typically involve cases in which one actors was a governmental actor and the other was an individual. This was true in all but eight of the progeny (1.6-percent of the effective sample). In these eight cases, the disputes were between two different individuals and typically involved a property dispute of some type.

If the sampling procedure was successful at producing a random sample, we also expected that the percentage of cases by state would be roughly equal in both the sampling frame and the eventual sample (i.e., not the effective sample). Figure A1 shows that the number of cases per state varies considerably, as would be expected given the substantial differences in state judicial culture and behavior. But we are more interested in whether these numbers correspond in a sensible manner to the proportion of cases by state in the sampling frame.

[Figure A1 about here]

We examined this by aggregating the number of cases in both the sampling frame and sample to the state level. We then computed a regression in which the percentage of state cases in the sampling frame was used to predict the number of cases in the sample. If the sampling procedure was accurate, we would expect the regression line to have an intercept of zero and a slope of .16, because we randomly drew sixteen percent of the 
frame for our sample. Figure A2 shows a scatterplot of the number of cases in the sampling frame on the number of cases in the sample, with an actual regression estimate and a line representing a perfectly representative and random sample. According to this graph, our sampling procedure slightly underrepresented states that had the most number of cases in the sampling frame because the actual regression line is shallower than the random sample line. At the same time, the slope estimate $\left(\beta^{*}=.14\right)$ is remarkably similar to the random sample slope ( $\beta=.16)$. And, while there may be some slight heteroskedasticity in the real regression estimate, the actual observations are clustered quite closely around the line. This suggests that the number of cases per state in the sampling frame is quite similar to the number in the sample, suggesting a high degree of representativeness across states.

[Figure A2 about here]

As a final check on the quality of our sample, we wanted to ascertain whether we might have to account for a sample selection bias in the dependent variable. In other words, we decided it was important to determine whether or not there was correlation between the dependent variable and the cases in the sample. Since we only have information on the dependent variable for our sample, we can only determine whether this correlation exists for the sample data. If there was no sample selection problem, we expected that there would be no relationship between the number of cases in a sample and the percentage of cases within each state that complied with Supreme Court precedent (we collapsed the two types of noncompliance). Figure A3 shows a scatterplot of the number of cases in the sample and the percent of noncompliance in each state. As this display clearly demonstrates, there is a negligible relationship between these two 
variables. This implies that the sample is not biased by having cases from states that exhibit abnormally high or low patterns of noncompliance.

[Figure A3 about here]

Based on these analyses, we concluded that we did not draw an odd sample and that, in fact, the sample was a reasonable representation of the universe of cases in our sampling frame. 
Figure A1. Progeny Per State. This depicts the number of state supreme court progeny in each state in the sample. It demonstrates a high level of variation between the states.

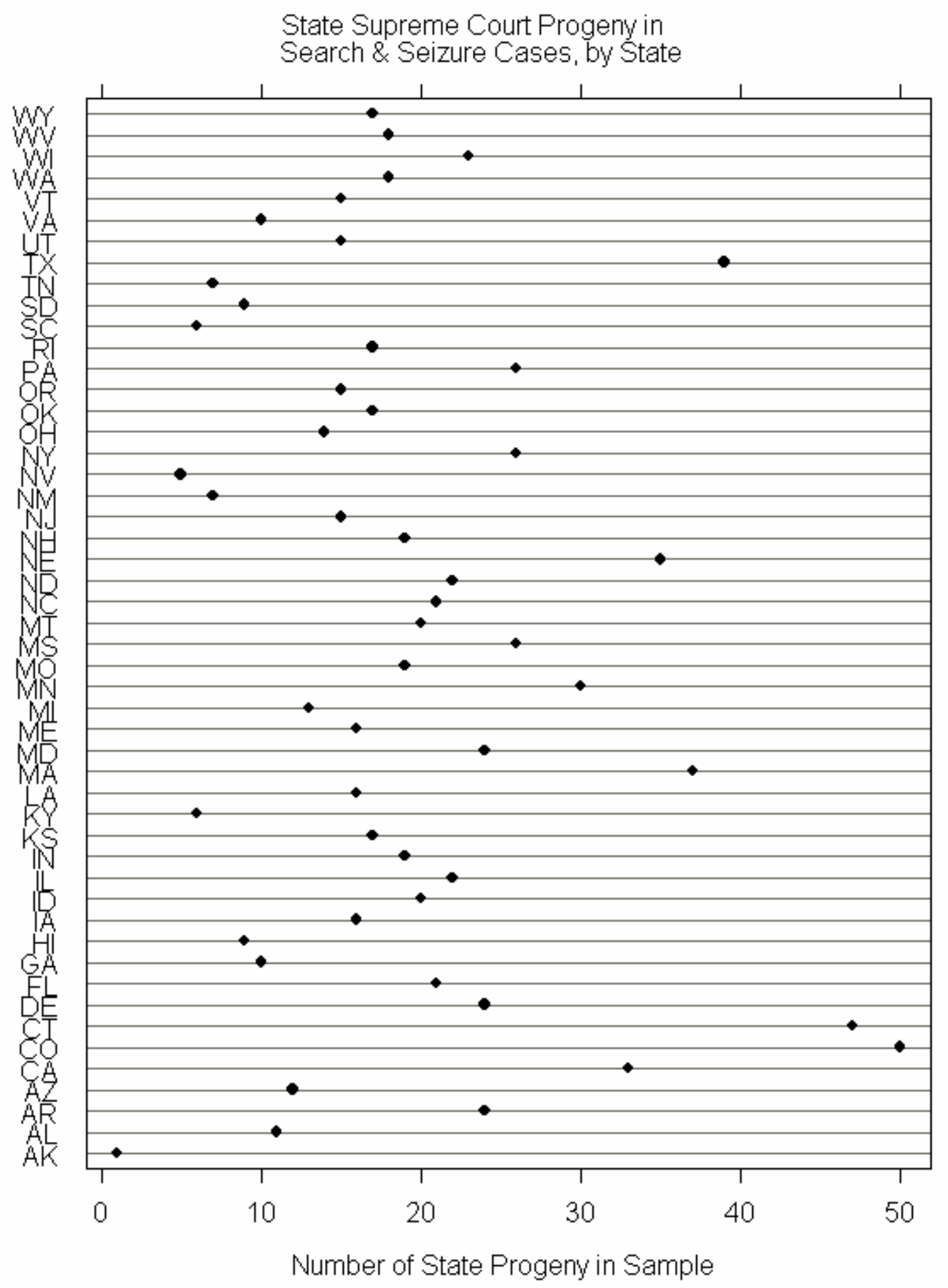


Figure A2. Number of Cases Per State in the Sample versus the Sampling Frame. This graph plots the number of state supreme court progeny in each state that were in the sampling frame against the number of progeny per state in the sample. The dotted line shows the predicted regression equation for a successful random sample, with intercept equal to zero and slope equal to .16. The solid line runs more shallow than that, showing that our sample slightly over-represents those states that cite Supreme Court precedent less frequently.

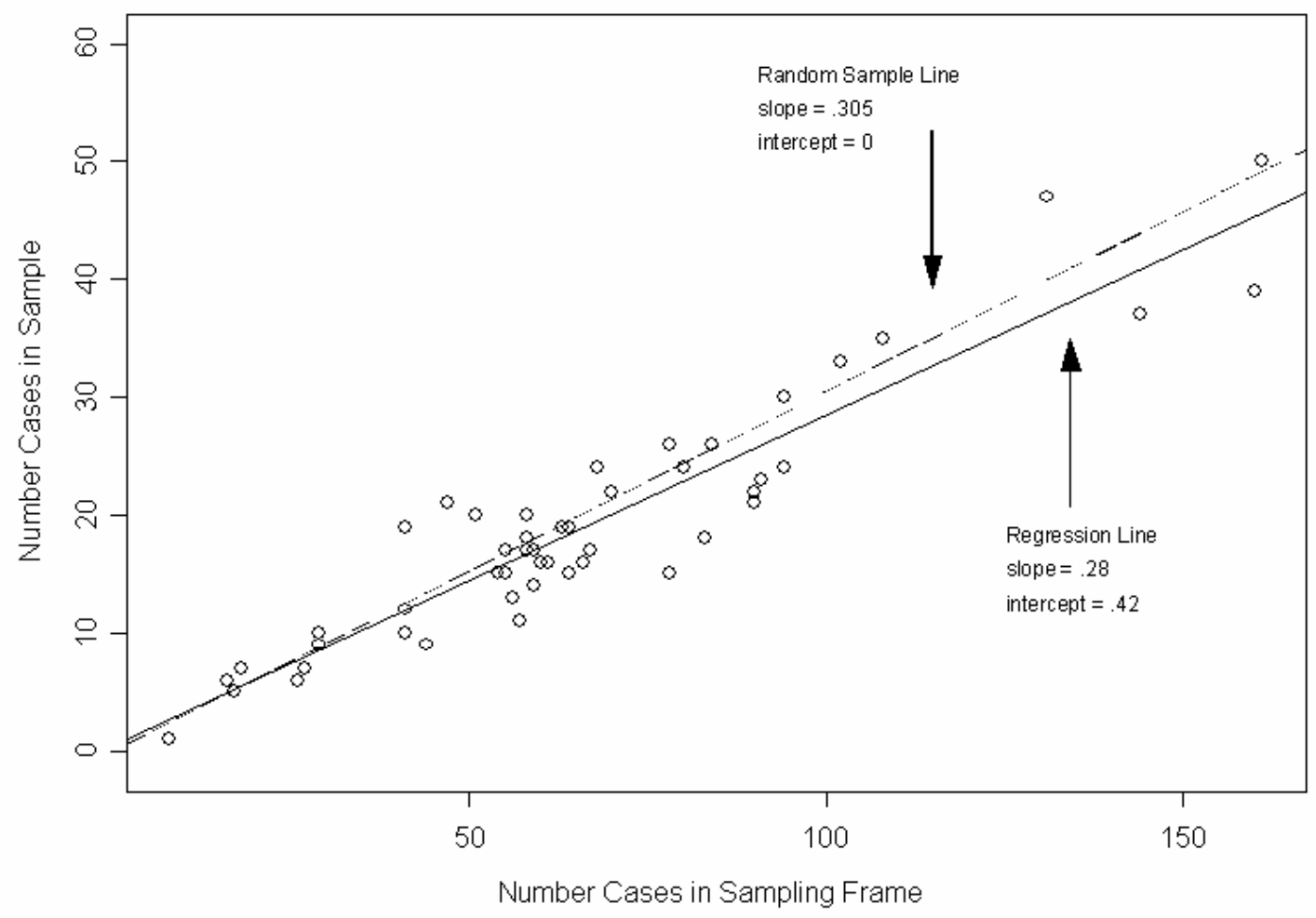


Figure A3. Number of Cases Per State in the Sample and State Supreme Court

Consistency. This graph plots the number of state supreme court progeny in each state that were in the sample as a function of state disagreement with the cited Supreme Court. This graph shows that the sample cases are not dependent on the extent to which state higher court decisions are consistent with the U.S. Supreme Court.

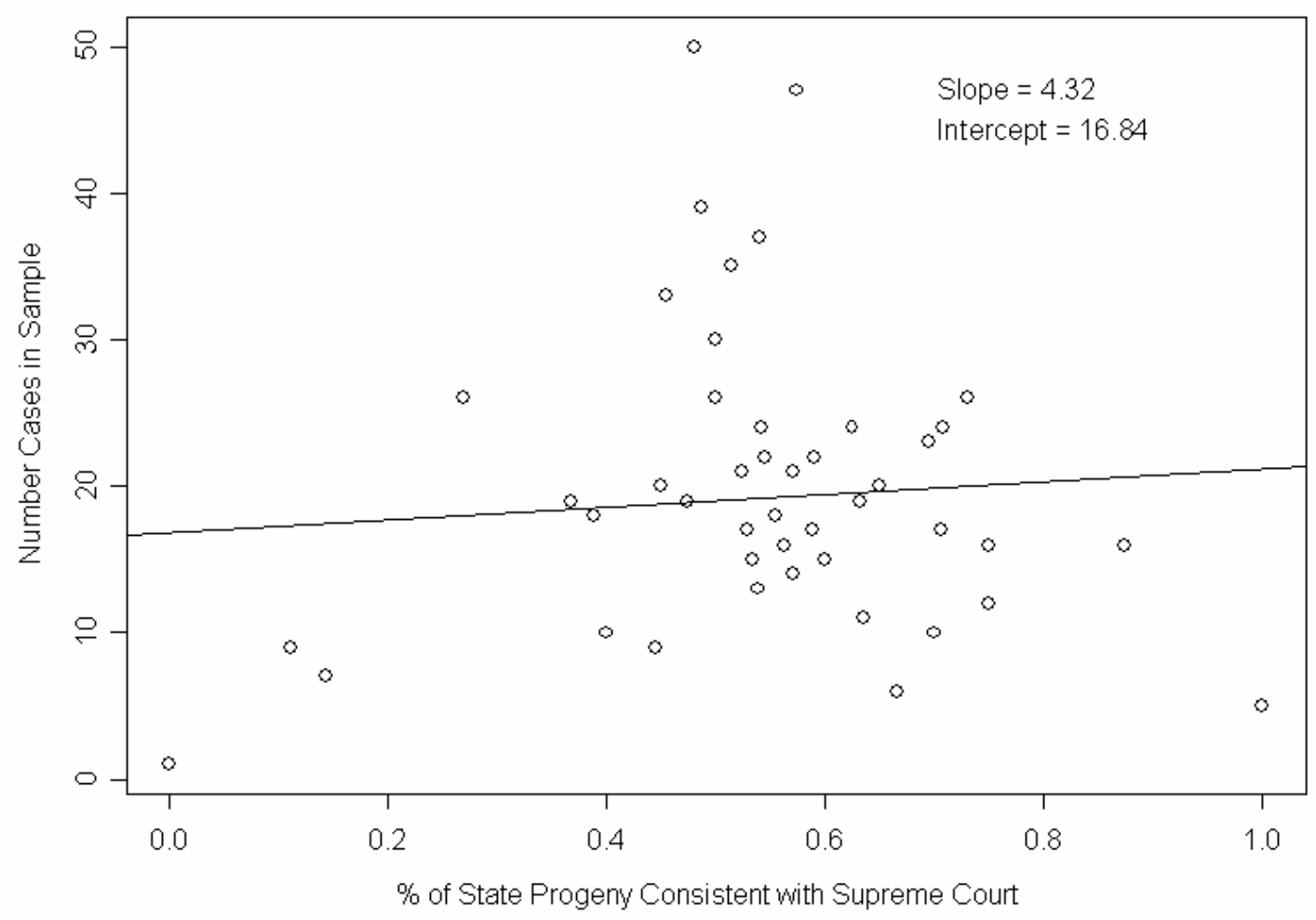




\section{Appendix B. Impact of Case Facts, Frequency of Reversal, and State Judicial}

\section{Institutions for Conservative Supreme Court Precedent.}

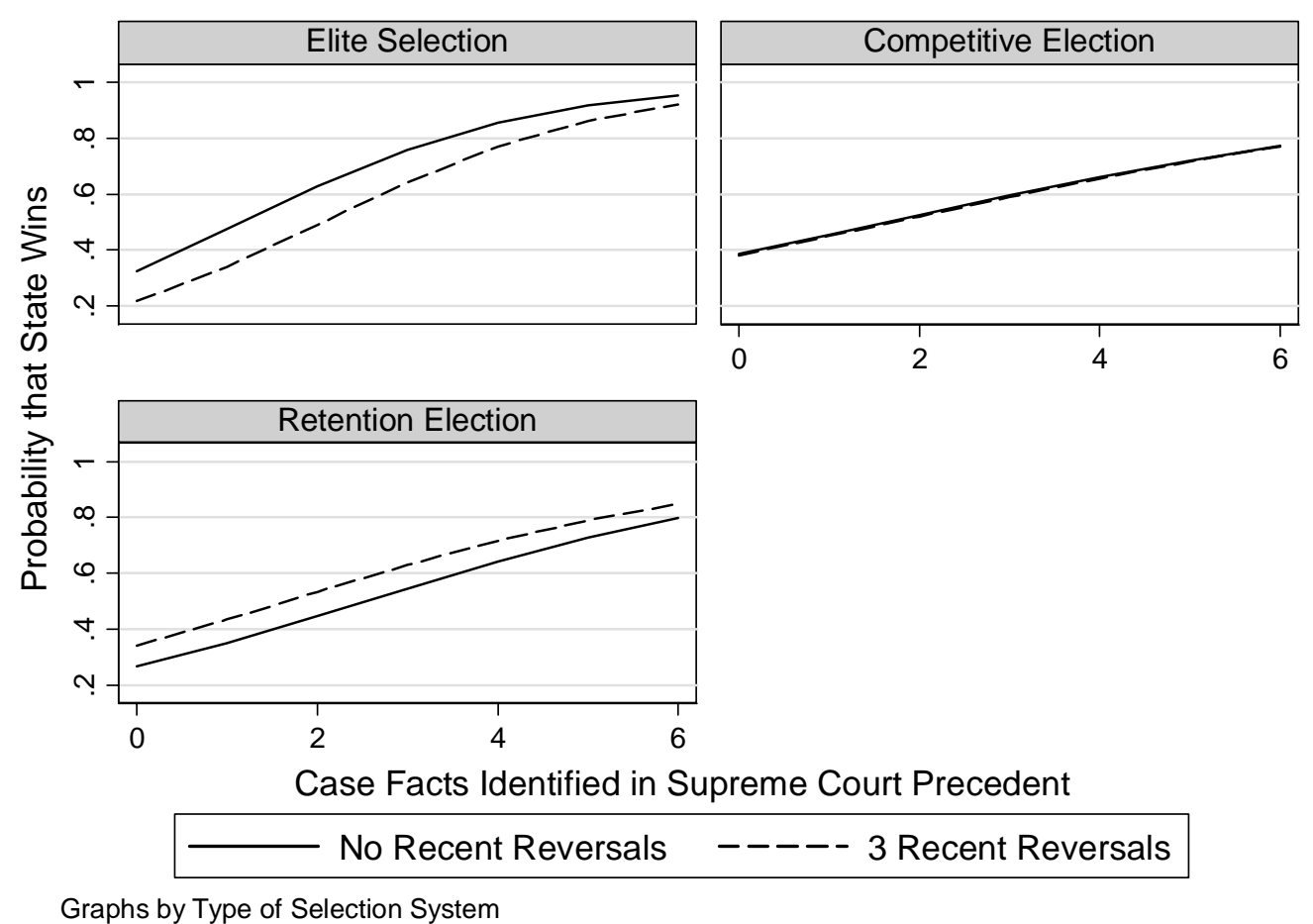




\section{Endnotes}

${ }^{1} 463$ US 1032, 1983.

${ }^{2}$ We can borrow an analogy from the bureaucracy literature to help make this point. In elite systems, monitoring is closer to "police patrols" where the elites monitor the courts with some regularity. By contrast, electoral systems are more of a "fire alarm" system where the monitors - in this case the public pay closer attention when problems arise.

${ }^{3}$ These data were collected from "The Original United States Supreme Court Judicial Database, 1953-2005 Terms" compiled by Harold Spaeth (2007).

${ }^{4}$ See Appendix A for full details.

${ }^{5}$ We consider the citation string the number of cases that are cited by the progeny as a group. Opinions will often discuss particular legal issues and conclude the paragraph with reference to a number of cases. We consider that if the state supreme court were to include the Supreme Court precedent in question in a citation string to be an effort to "hide" the cite from scrutiny in a potential effort to skirt that holding while at the same time attempting to raise any red flags that might lead to review and a reversal.

${ }^{6}$ The seven case facts are whether 1.) the search occurred in a home, 2.) the search occurred in a business, 3.) the search occurred in a car, 4.) the search occurred on a person, 5.) it was a full search, 6.) the search occurred after a warrant at been issued, and 7.) the trial court had determined the presence of probable cause. Although Segal (1984) enters these into his model separately, we find no differences in our key findings if we enter them as an index.

${ }^{7}$ As noted, there is a shift to the right in the political preferences of the Supreme Court. The analyses we present below do not change when accounting for this shift.

${ }^{8}$ The PAJID scores are measures of individual justices' political preferences. Our hypotheses, however, are about where the state courts stand in general since opinions are arrived at by all justices on the state courts. The traditional approach to dealing with this problem, which we employ here, is to use the median justice's score as a measure of the "swing point" on the court.

${ }^{9}$ We are grateful to Laura Langer for generously sharing these data. 
${ }^{10}$ This might be more accurately stated as there is a tendency in the electoral systems toward distinguishing themselves from cited Supreme Court precedent in these systems when they haven't been reversed frequently.

${ }^{11}$ In determining the impact of frequency of reversal, we controlled both the number of reversals and the value of interaction coefficient so that they both reflect their real values. For example, when the cited precedent is liberal, the interaction variable is zero. When it is conservative, it is equal to the value of the frequency of reversal.

${ }^{12}$ For purposes of these simulations, we define these as the $25^{\text {th }}, 50^{\text {th }}$, and $75^{\text {th }}$ percentiles of the PAJID variable.

${ }^{13}$ We have also calculated the substantive effect of case facts in cases citing conservative Supreme Court precedent and the results are quite similar. These results are contained in Appendix B. 